\title{
Barley B-amylase and B-glucanase activities at germination in vulgare-type lines from backcrosses of wild, spontaneum strains with cv. Adorra
}

\author{
HANNU AHOKAS and Maria J. ERKKILÄ
}

\begin{abstract}
AноKAS, H. \& ERKKILÄ, M.J. 1992. Barley B-amylase and B-glucanase activities at germination in vulgare-type lines from backcrosses of wild, spontaneum strains with cv. Adorra. Agric. Sci. Finl. 1: 339-350. (Agric. Res. Centre of Finland, Inst. Plant Breed., SF-31600 Jokioinen and Univ. Helsinki, Dept. Genetics, Arkadiankatu 7, SF-00100 Helsinki, Finland.)
\end{abstract}

\begin{abstract}
Two hundred and nineteen lines derived from the backcross progenies of eight different Hordeum spontaneum strains were evaluated for B-amylase and B-glucanase activity five days after germination under aseptic conditions. The activities were determined on the basis of soluble protein or grain mass. The recurrent parent cultivar, Adorra, served as the standard. Putative recombinants with high B-amylase activity were relatively easily achieved from high-activity strains of $H$. spontaneum. Recombinants with high B-glucanase were rare. They appear to be eliminated, possibly due to the strong selection for the domesticated phenotype during the derivation process.
\end{abstract}

Key words: barley breeding, carbohydrate hydrolases, gene linkage, genetic resources, Hordeum spontaneum, malting barley

\section{Introduction}

The earliest recognition of the wild progenitor of barley (Hordeum vulgare ssp. spontaneum, or $\mathrm{H}$. spontaneum) as a source of genetic variation of the grain constituents dates back to the 1970s. Breeders have largely ignored the use of wild barley as breeding material, supposedly because of the following reasons: highly shattering spikelets, need of manual cleaning of grains, vernalization requirement for growing under long-day conditions, apparent low grain yield and limited availability of material from the original habitats. Biologically $H$. spontaneum belongs to the same species as the domesticated barley. Shattering of spikes and firmness of awns appear predominantly in the $F_{1}$ 's and subsequent generations after crossing with the domesticated barley, necessating extra careful manual work.

The chemical composition of the wild barley grain attracted attention when high protein contents were observed in material from in original habitats in Israel (LADIZINSKY 1975) and cultivated sources (AHOKAS 1977). Variations were described in the protein and lysine contents (AHOKAS 1982); the lysine content was later reported to be principally under polygenic control (AHOKAS 1990). CORKE and ATSMON (1988) observed significant positive correlation of lysine with most of the amino acids in wild barley genotypes. Many different hordein patterns were shown to be present (DoLL and BRown 1979, Nevo et al. 1983) and to correlate with environmental parameters in Israel (NEvo et al. 1983). The grain mineral contents were mostly higher in a wild barley than in a standard cultivar 
(FRIEDMAN and ATSMON 1988). Wild barley was shown to be a rich genetic source of variation of trypsin inhibitor in endosperms (KIRSI and AHOKAS 1983), while 22 Finnish cultivars or breeding lines of barley were relatively uniform (KIRSI 1973, KIRSI, personal communication).

Of the enzymes of the germinating grains interesting to brewing or malting, unique $\alpha$-amylase isoenzyme patterns, especially at the $\alpha$-amylase 2 locus, have been detected in wild barley in addition to the normal ones (BROWN and JACOBSEN 1982). Of the six enzyme activities studied in vitro among 175 strains of wild barley $\beta$-amylase and B-glucanase varied most widely in extracts of wild barleys germinated for five days (AHOKAS and NASKALI 1990 a). The activity estimates for five enzymes of 242 strains mostly correlated with the moisture parameters of the territory of origin in the Near East (AHOKAS and NASKALI 1990 b).

So far, little has been published on the transfer of genes responsible for grain quality from wild barley to domesticated backgrounds (BROwN et al. 1988, АHOKAS 1990, Ellis et al.1991, MACLEOD et al. 1991), while the crossing programmes to transfer disease resistance genes to domesticated barley are older. Nevo (1992) has recently published a review on disease resistance and other useful sources in $H$. spontaneum. We report here the recombination of genotypes responsible for high activities of two enzymes, $\beta$-amylase and $\beta$-glucanase, in some of the backcrossed progenies. The selection of genotypes for domesticated barley morphology had been done for five generations.

\section{Material and methods}

The grain material was derived from the crossing of H. spontaneum/2*Adorra by Hannu Ahokas since 1978. The grain material used here was produced in single row plots of a length of about $1 \mathrm{~m}$, average plant distance about $4 \mathrm{~cm}$ and row distance $20 \mathrm{~cm}$, planted with a Plot Spider (Wintersteiger) planting machine. $\mathrm{Cv}$. Adorra was grown as the standard usually two rows per 120 rows, the nearest Adorra sample was used as the standard for the selected lines the yield of which represented the $\mathrm{BC}-\mathrm{F}_{6}$ generation. The material was grown in 1985 on the field of Anttila Experimental Farm on gyttja clay soil under the standard field practice of the Hankkija Plant Breeding Institute.

The rows of morphologically uniform and acceptable lines were harvested in binds by hand, dried under air stream at room temperature, and threshed with a Saatmeister (Kurt Pelz) seed cleaner. After storage for about one year at room temperature the grains were stored at about $-15^{\circ} \mathrm{C}$ for four years. Germination was good, with no postharvest dormancy. Undamaged grains were husked manually, sterilized and rehusked with a treatment of $50 \%$ $\mathrm{H}_{2} \mathrm{SO}_{4}$, and germinated aseptically for five days at $15^{\circ} \mathrm{C}$ in the dark as described elsewhere (AHOKAS and NASKALI 1990 a). The extracts of the homogenates of the germinating grains in toto were used for the enzyme assays. The activity of $B$-amylase was assayed using a Betamyl kit (Biocon) which is an equivalent of the Testomar-Amylase Mono kit we used previously (AHOKAS and NASKALI 1990 a). The activity of B-glucanase was assayed as described by AHOKAS and NASKALI (1990 a) with azo-barleyglucan (Biocon). The samples were worked in groups of twelve, each including an Adorra standard from the nearest row. The protein content of extracts was determined with the BCA assay (SMITH et al. 1985) using a reagent purchased from Sigma and bovine serum albumin (Sigma A-4503) as the standard.

The 'BS' strains have previously been referred as '79BS' (AHOKAS 1981), but for simplicity appear here in the short form.

\section{Results}

The number of plants obtained from the $\mathrm{BC}-\mathrm{F}_{2}$ population of $H$. spontaneum/2*Adorra lies in the range of 1 to $4 \%$. The selection criteria were rachis toughness, grain abscission from rachis, softness of awns and spring growth habit under long-day conditions. Selection took place at harvest by feeling each non-shattered mature spike. The same criteria were applied in the subsequent generations, where 
increasing importance was also given to straw characteristics. The selected lines used here would in most cases need a single additional crossing step with a current elite cultivar to breed a competitive cultivar with properties of the current high-enzyme lines.

The strict selection for morphology usually tends to reduce drastically the final number of $\mathrm{F}_{6}$ lines obtained. The present material would therefore not show recognizable genes in any expected proportion. Without selection the allele frequency of the cultivar Adorra would be 0.75 , and that of the wild partner 0.25 .

We consider bimodality of the activity distribution with another mode at the high-activity side to represent a recombination of a high-activity allele from the wild partner of the cross. The distribution is probably affected also by modifying genes, or inhibitors or activators in the extracts would interfere with the activity measurement. The determinations based on grain mass are more meaningful for breeders and farmers, while those based on protein content may be interesting to biochemists and industrial applications (Table 1, Figs. 1-8). The high protein contents of wild barleys seemingly lower the activities when calculated for protein and compared with domesticated barley which has some $50 \%$ of the protein content of wild barley (Table 1). When the protein content is lowered as a consequence of the segregation in the offspring, segregants with high enzyme activities for protein are unmasked.

The activities available from the original accessions of wild barley (Table 1) are not fully comparable with the present determinations, because of the somewhat different growing conditions and the different kit used for determination of $\beta$-amylase. However, these determinations are valuable when assessing the usefulness of screening of the material before assuming a breeding programme. The activity of the wild barley accession BS 06-4, the seed of which was originally collected in bulk with BS 06-2 by Prof. Moshe Feldman in the same site in Israel has not been determined. BS 06-4 is also considered to be interesting, since BS 06-2 and BS 06-4 are phenotypically similar.

The enzyme activities are presented in Figures 18. The range of 0.3 to 1.7 for relative activity is expected to include practically all the segregants with an activity of the Adorra level, if distributed normally. Activities 1.7 times or more that of cv. Adorra were measured for B-amylase in lines of BS 05-1 (for protein and grain mass), those of BS 06-2 (for grain mass), those of BS 06-4 (for protein and grain mass), those of BS 13-3 (for protein and grain mass), those of BS 16-2 (for grain mass) and in those of R 1163-07 (for protein and grain mass). A second mode is evident at the high-activity ends of the

Table 1. Determinations of B-amylase and B-glucanase activity in the seed parent accessions of wild barley used for the derivation of the present material. B-Amylase was determined with a Testomar-Amylase Mono kit and B-glucanase by the present method. (AHOKAS and NASKALI, unpublished data.)

\begin{tabular}{|c|c|c|c|c|c|c|c|c|}
\hline \multirow{3}{*}{$\begin{array}{l}\text { Accession } \\
\\
\text { BS 05-1 }\end{array}$} & \multicolumn{4}{|c|}{ B-Amylase $(\mathrm{U})^{*}$} & \multicolumn{4}{|c|}{ B-Glucanase $(\mathrm{mU})^{*}$} \\
\hline & \multicolumn{2}{|c|}{$\begin{array}{l}\text { For protein } \\
(\mathrm{mg})\end{array}$} & \multicolumn{2}{|c|}{$\begin{array}{l}\text { For grain mass } \\
\qquad(\mathrm{g})\end{array}$} & \multicolumn{2}{|c|}{$\begin{array}{l}\text { For protein } \\
\quad(\mathrm{mg})\end{array}$} & \multicolumn{2}{|c|}{$\begin{array}{c}\text { For grain mass } \\
(\mathrm{g})\end{array}$} \\
\hline & 14.6 & [0.92] & 613 & [1.65] & 17.5 & [0.79] & 734 & [1.40] \\
\hline BS 06-2 & 16.4 & [1.05] & 766 & {$[2.28]$} & 32.9 & [1.53] & 1539 & [3.31] \\
\hline BS 13-3 & 9.9 & {$[0.35]$} & 518 & {$[0.83]$} & 23.7 & {$[1.45]$} & 1240 & [2.92] \\
\hline BS 16-2 & 16.1 & {$[0.81]$} & 665 & [1.73] & 21.4 & {$[0.84]$} & 880 & [1.78] \\
\hline PI 391105 & 8.5 & {$[0.63]$} & 205 & {$[0.73]$} & 32.4 & {$[1.40]$} & 786 & {$[1.64]$} \\
\hline R 1161-06 & 16.2 & {$[0.67]$} & 906 & {$[2.02]$} & 34.5 & [1.79] & 2100 & {$[5.85]$} \\
\hline R 1163-07 & 16.2 & {$[0.60]$} & 992 & {$[1.57]$} & 25.2 & [1.29] & 1544 & {$[3.23]$} \\
\hline
\end{tabular}

* Values in brackets are the calculated equivalents to units in Figs. 1-8. 
a

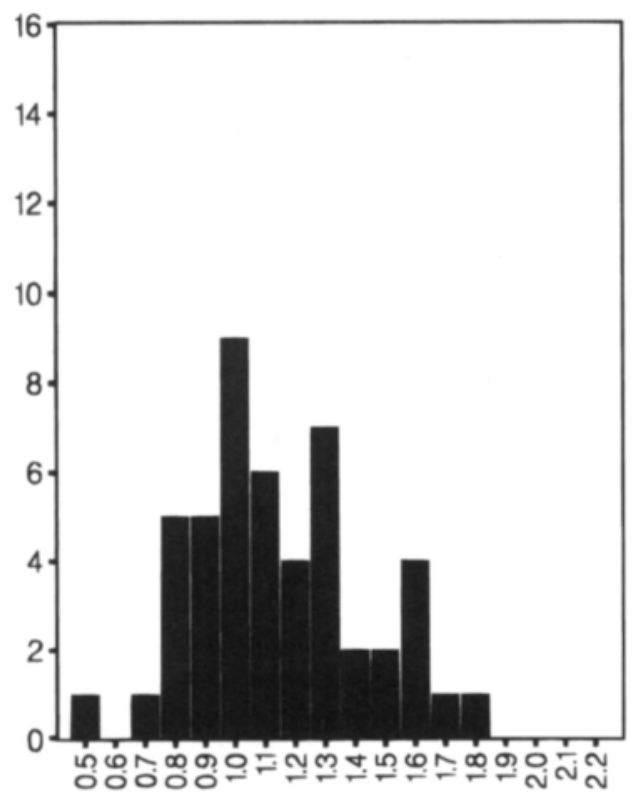

b

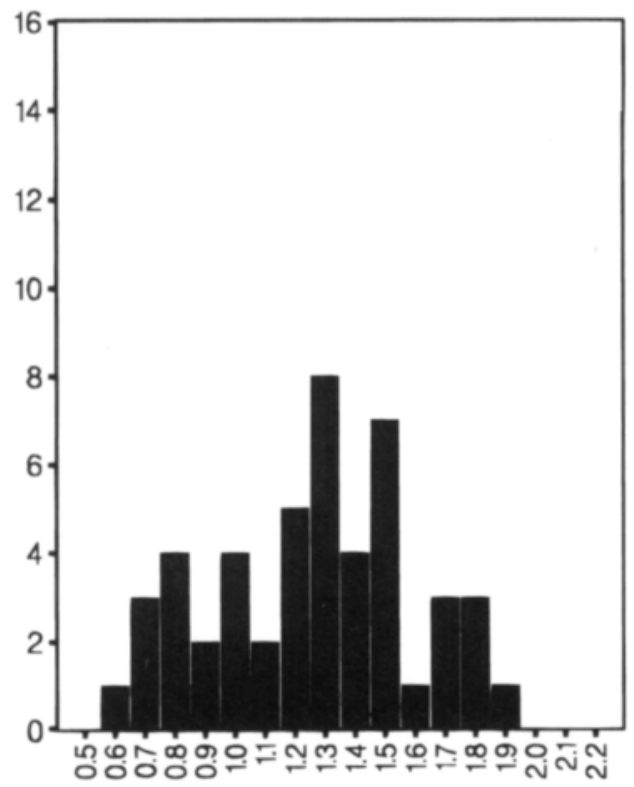

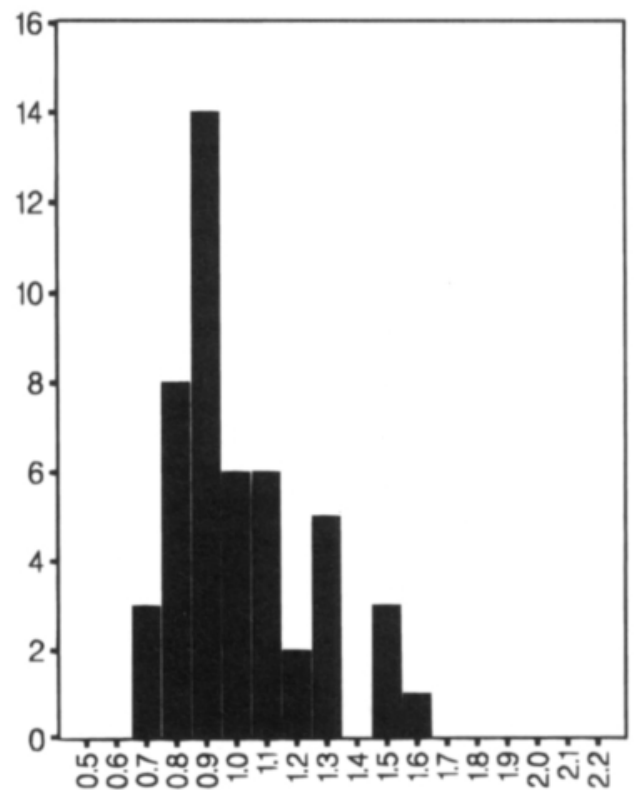

C

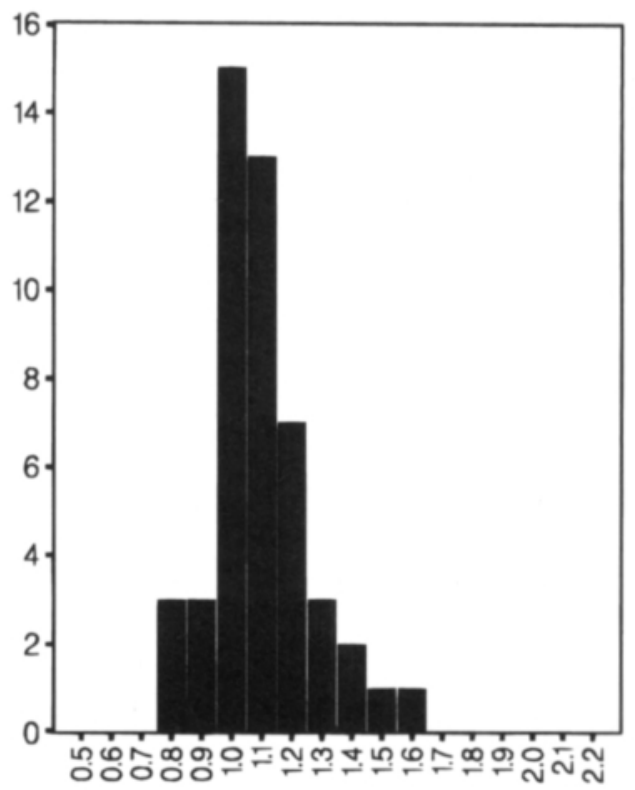

Figs. 1-8. Distribution of the activities of $B$-amylase (a and b) and B-glucanase ( $c$ and $d$ ) among the selected lines in relation to the recurrent parent, cv. Adorra as the standard sample, whose value equals 1.0. Plots (a) and (c) have been calculated for protein and plots (b) and (d) for grain mass. The ordinate indicates the sample size. - Fig. 1. Progeny of the cross BS 05$1 / 2^{*}$ Adorra. Several high-activity lines for $\beta$-amylase appear in the mode at about $1.6 \mathrm{in}$ (a) and 1.75 in (b). 
a

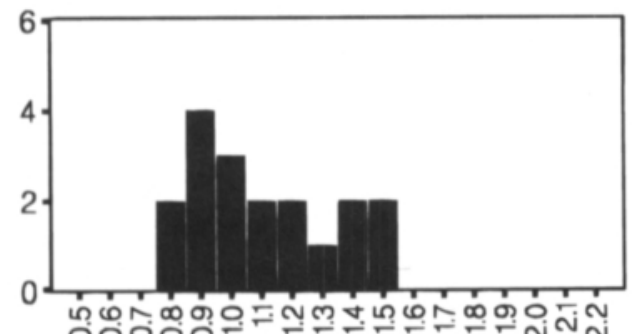

b

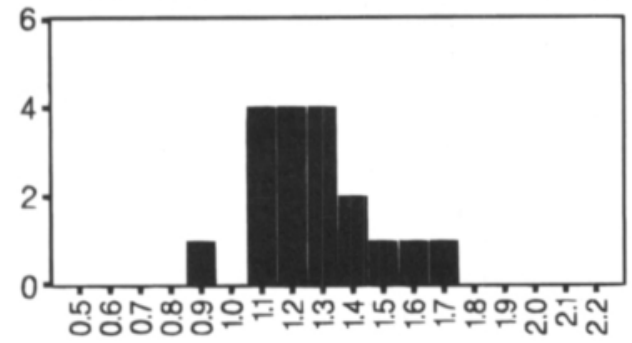

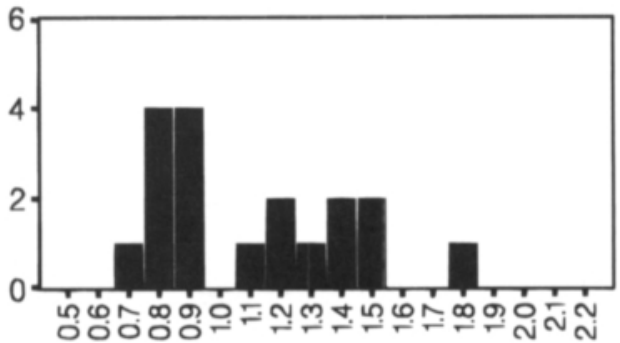

C

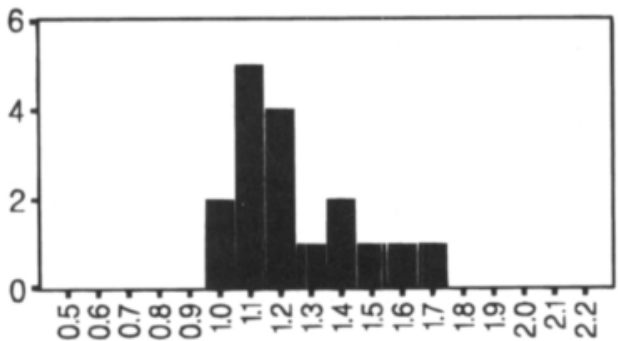

Fig. 2. Progeny of the cross BS $06-2 / 2^{*}$ Adorra. High values observed especially for B-glucanase activity with an apparent high-activity mode at 1.45 in (c) and 1.4 in (d).

a

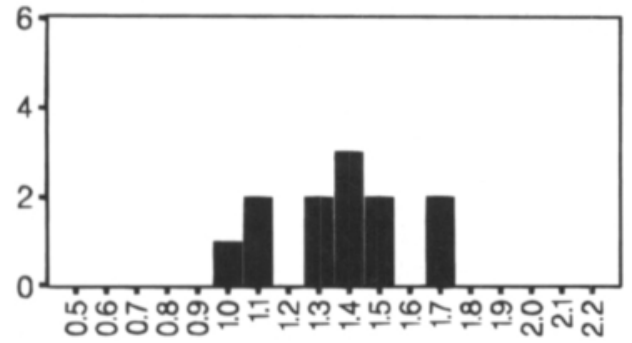

b

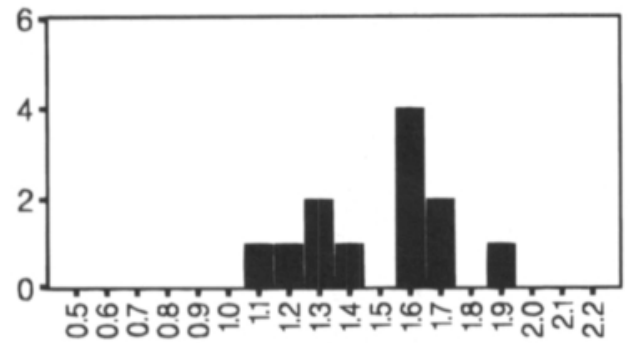

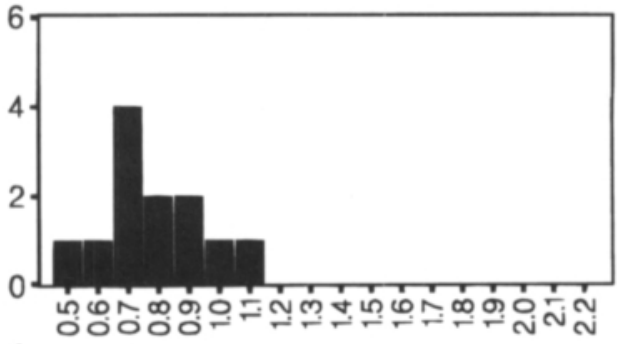

C

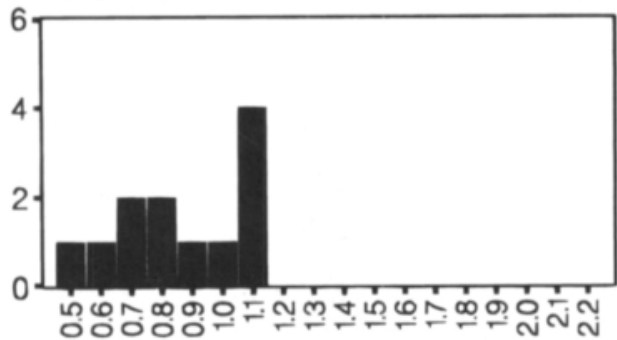

Fig. 3. Progeny of BS 06-4/2*Adorra. High-activity lines of B-amylase in (a) and (b).

distributions of $\beta$-amylase activities for the derivatives of BS 05-1, BS 13-3, BS 16-2, R 1161-06 and R 1163-07 (Figs. 1b, 4a, b, 5b, 7a,b and 8a, b).

For $\beta$-glucanase, the activity level 1.7 times that of cv. Adorra was reached only in the offspring of BS 06-2 (Fig. 2c, d). Strains BS 05-1 and R 1161-6 might also be useful cross partners in breeding an increased B-glucanase activity (Figs. 1c, d, and 7c, d). 
a
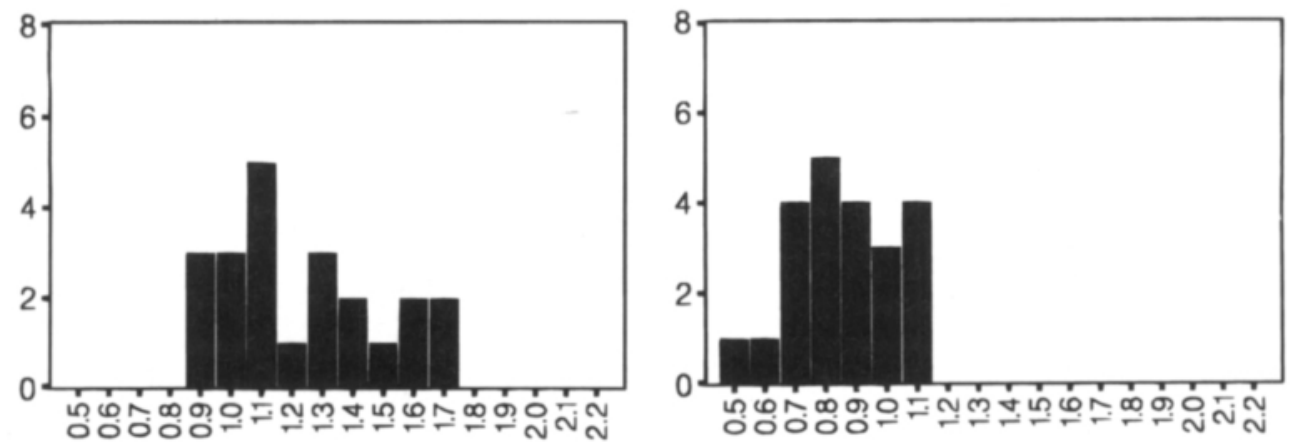

b
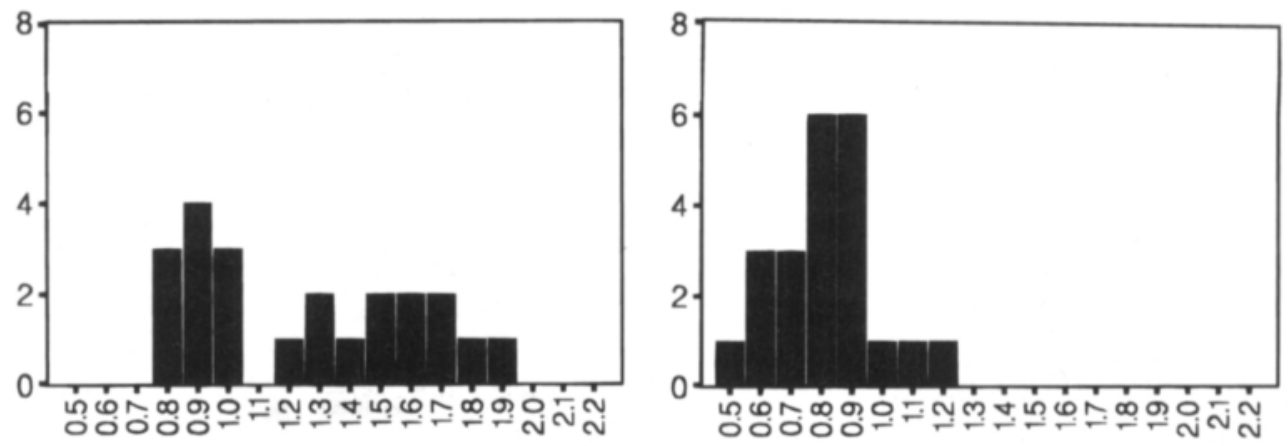

Fig. 4. Progeny of BS 13-3/2*Adorra. An apparent high-activity mode of B-amylase at 1.6 in (a) and 1.55 in (b).

a

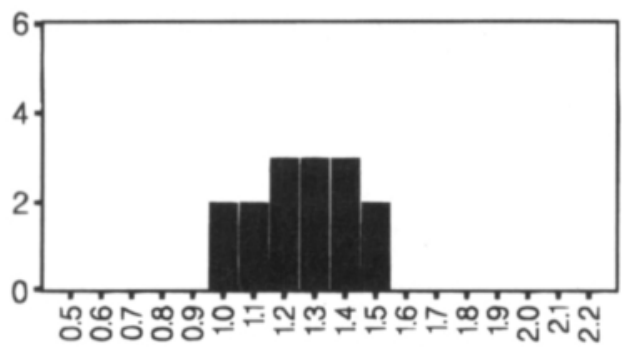

b

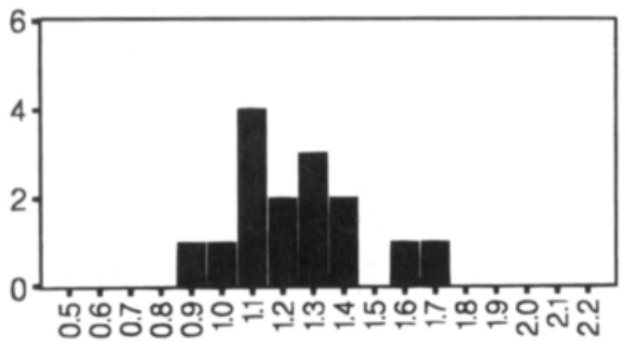

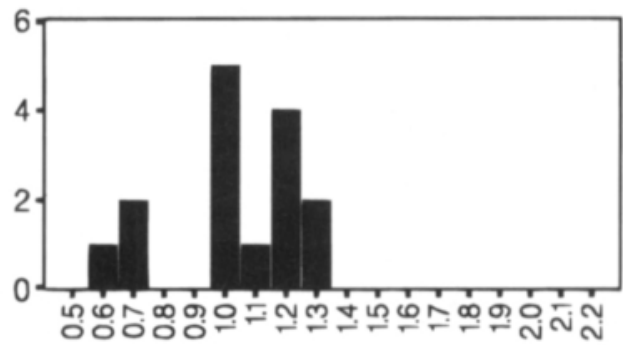

C

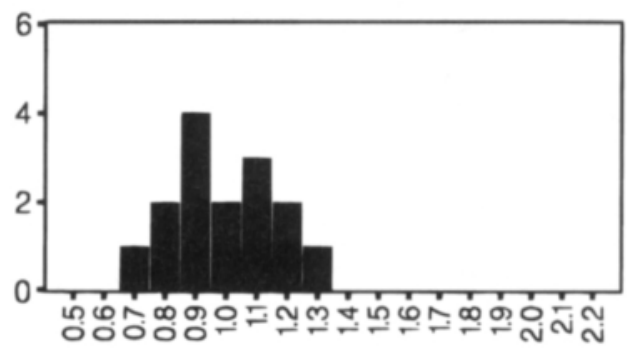

Fig. 5. Progeny of BS $16-2 / 2^{*}$ Adorra. High-activity lines of $B$-amylase in (b). 
a

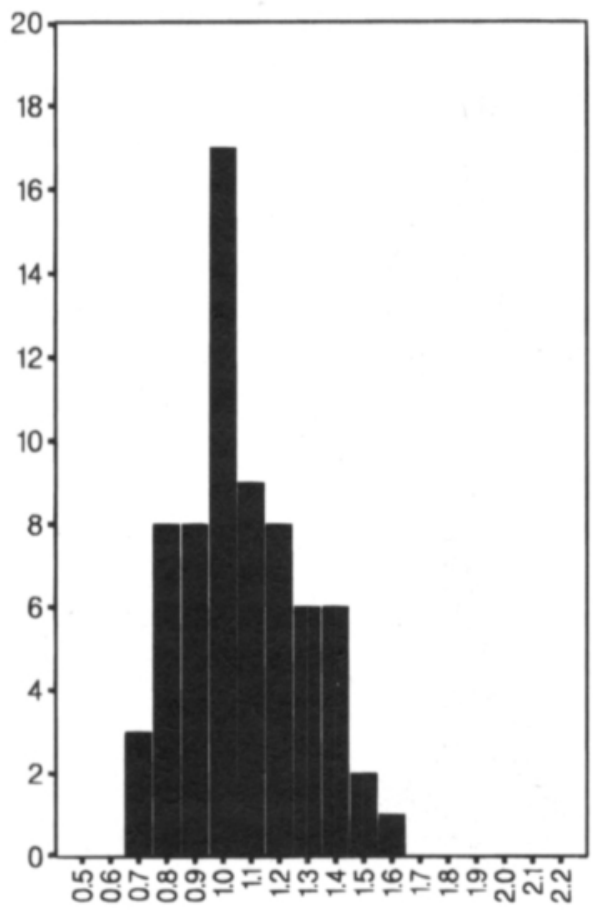

b

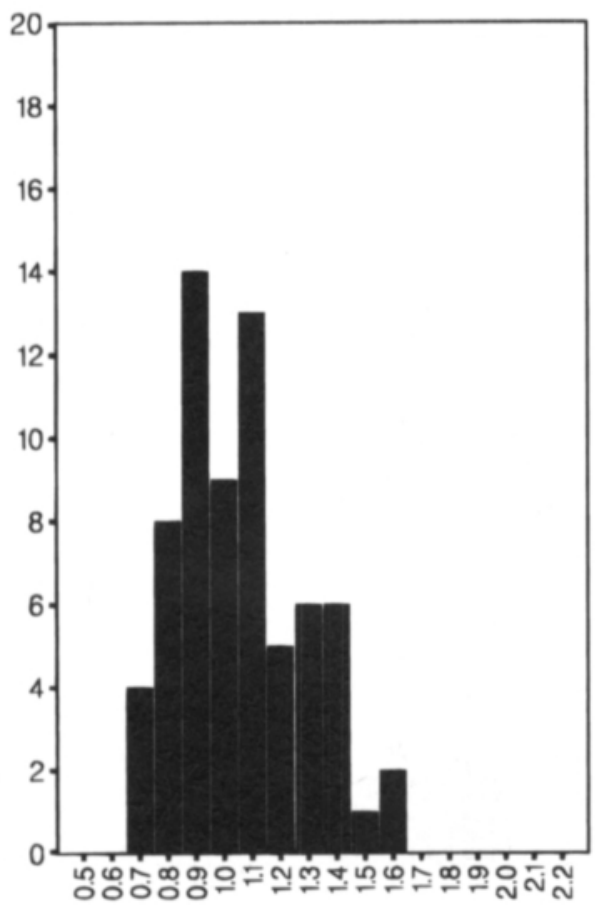

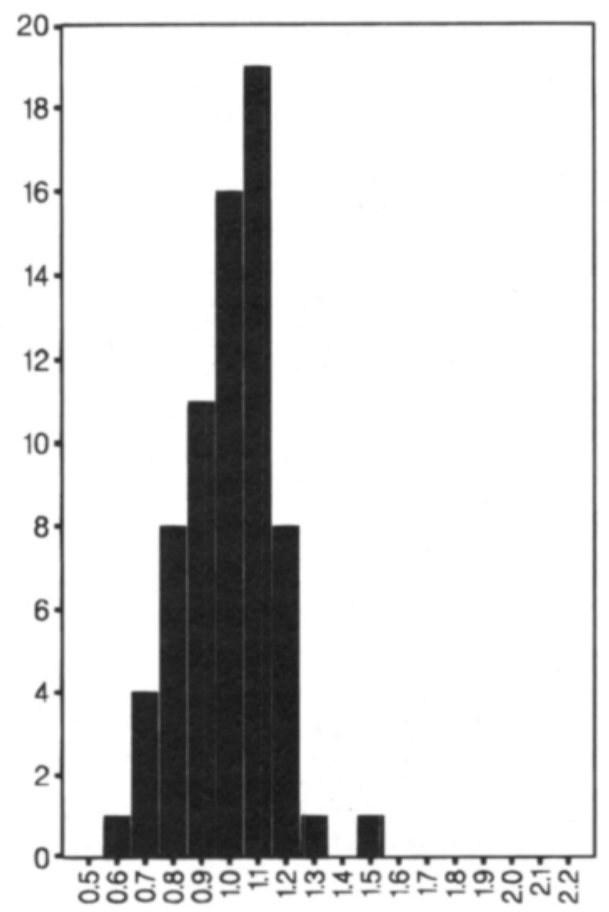

C

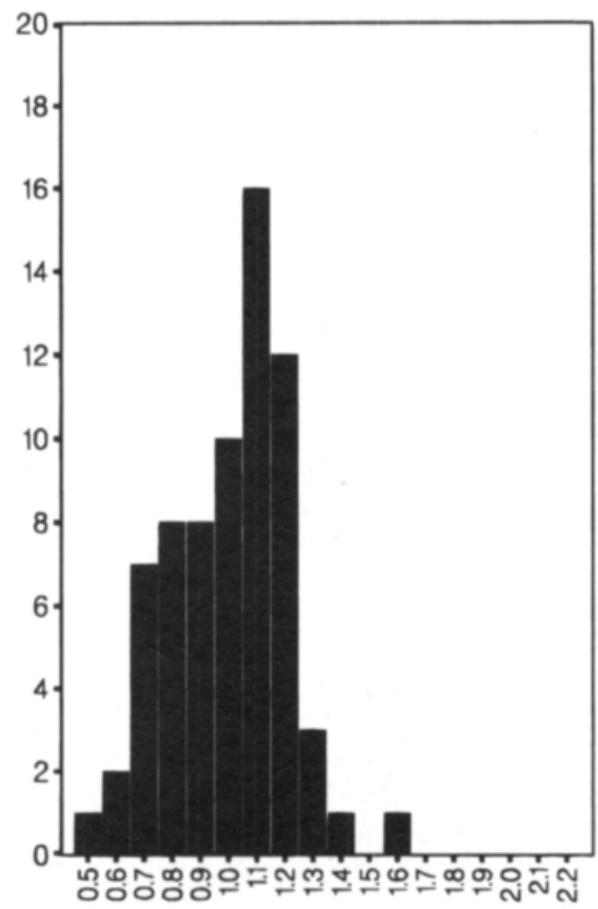

d

Fig. 6. Progeny of PI 391105/2*Adorra. No great deviations from normality. The accession PI 391105 was selected because of its relatively high $B$-glucanase activity (Table 1 ). 
a

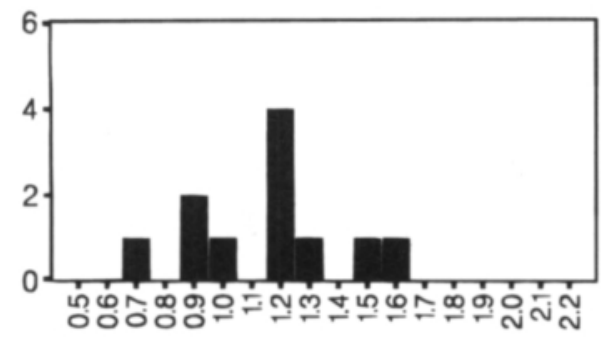

b

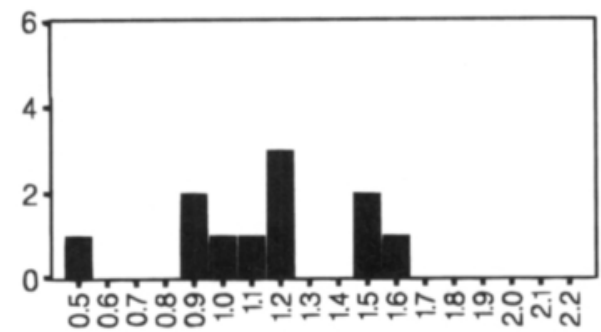

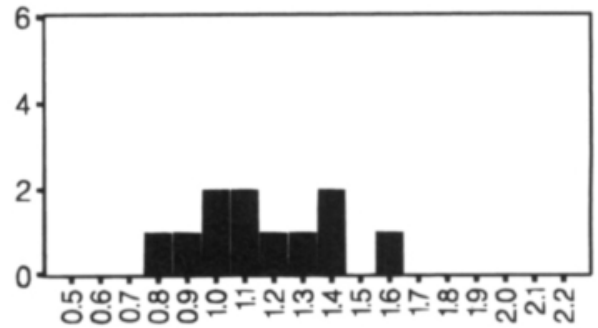

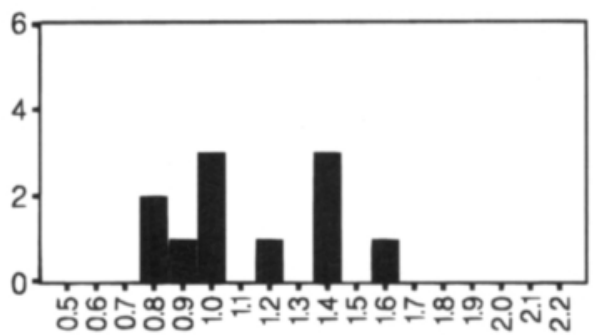

Fig. 7. Progeny of R $1161-06 / 2^{*}$ Adorra. R $1161-06$ is evidently a promising parent for increasing B-amylase and B-glucanase activities.
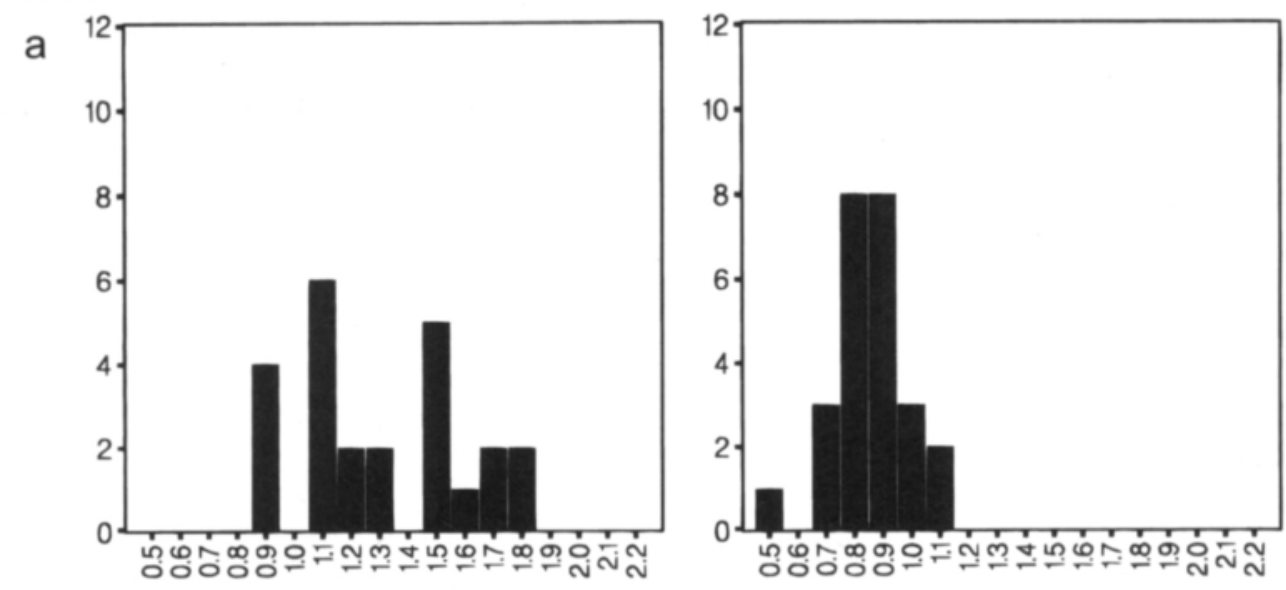

C

b

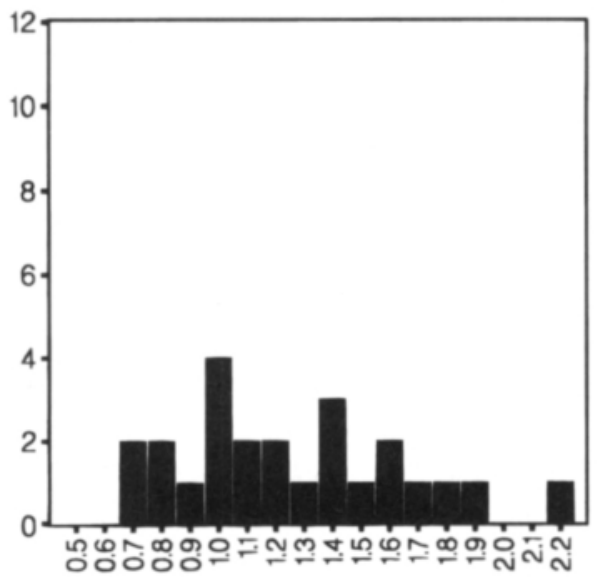

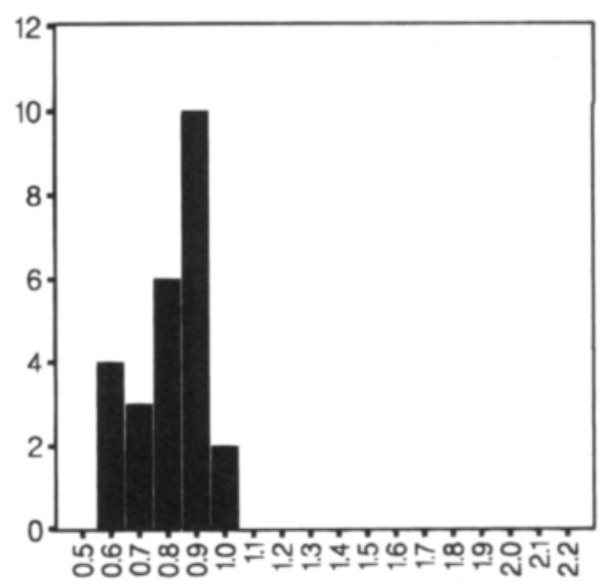

d

Fig. 8. Progeny of R 1163-07/2*Adorra. R 1163-07 is evidently a promising parent for breeding high activity of B-amylase. 


\section{Discussion}

The germination time of the sterilized grains under axenic conditions was 120 hours or five days and was chosen as a compromise. The activity of B-glucanase is known to increase substantially still at a later stage of germination (PREECE and HoGGAN 1956, BouRne and PIERCE 1970). Inversely, B-amylase occurs at the same level in resting grains as in their malt (VISURI and NUMMI 1972), and another Bamylase gene may be present in non-grain tissues (KREIS et al. 1988). Of the stored B-amylase, about $60 \%$ is bound and mainly released between days 1 and 3 of germination (SOPANEN and LAURIERE 1989). The B-amylase appears in proteolytically processed forms in barley (LUNDGARD and SvENSSON 1987). The extent of release and processing of B-amylase after five days may be the sources of variation of activity other than that caused by the alleles themselves.

Two (WoOdward and Fincher 1982), or possibly three, (STUART et al. 1986) isoenzymes of 1,$3 ; 1,4-\beta$-endoglucanases are present in germinating barley grain, two of them being coded by different gene loci (LoI et al. 1988, SLAKESKI et al. 1990, MACLEOD et al. 1991).

The activity level in vitro and possibly also in vivo is, however, often modified by specific or unspecific inhibitors or activators, making the segregation of the enzyme genes less clear. A high concentration of an endogenous inhibitor may also mask the product of a high-activity enzyme allele in the original wild barley line. The level of $\beta$-glucanase mRNA in barley aleurones is controlled by natural phytohormones - gibberellin increasing and abscisic acid decreasing it - during germination (LiTTs et al. 1990). The protein $\beta$-amylase possesses an enzyme inhibitor capability in sweet potato (PAN et al. 1988).

After five generations of selfing of the back-crossed derivatives, one line in 16 is expected to carry without selection both the parentally different alleles as well as their heterozygotes in the ear-to-row model. This frequency of heterogeneity is not expected to abolish the value of the activity deter- minations for a distribution pattern.

The genes for brittle rachis, probably concerning also $H$. spontaneum, have been allocated to chromosome 3 (TAKAHASHI and HAYASHI 1964). Thus, the strong selection pressure for the domesticated non-brittle rachis type in these cross derivatives is not assumed to affect the distribution of the loci for $B$-amylase and B-glucanase known to reside in other chromosomes. A difficulty might be expected to arise from the tight linkage of the winter habit gene and the $B$-amylase gene on chromosome 4 (СHOJECKI et al. 1989). The Israeli H. spontaneum barleys require vernalization when grown in Finland, but most proveniences set spikes without vernalization in original habitats in Israel (Prof. Dan Atsmon, personal commununication). The reason for this difference must be the response to the day length. In Israel, H.spontaneum is a short-day plant with spike initiation in winter or early spring, while under the almost continuous daylight in the early season in Finland the plants behave as long-day plants. The switch from short-day to long-day response is probably caused by the vernalization. It is not known, whether the linked winter growth habit locus on chromosome 4 is associated with photoperiodic responses among the three loci which determine the spring/winter growth habit on chromosomes 4, 5 and 7 (TAKAHASHI and YASUDA 1971). With some wild barley genotypes, the recombination of the $B$-amylase gene into spring barley background may be problematic.

When there is pollen carrying different alleles of $\beta$-amylase available at pollination, one of the genotypes can be at a relative advantage as compared with the other pollen carrying the different $B$-amylase allele, as shown for a backcross in barley, resulting in an unequal distribution (PEDERSEN 1988). Such a distortion of segregation may occur in heterozygotes of the $\beta$-amylase gene in the present material.

Bimodality of activity distribution with highactivity variants was observed in most crosses where the original wild barley used was known to have a high activity in B-amylase, but more rarely in B-glucanase. This may mean that the B-glucanase 
gene is linked with genes discriminated when selecting for the domesticated phenotype, but such an association is not present in $\beta$-amylase genes introduced from the wild barley to the derivative. The high-activity lines should be repeatedly studied after regrowing in order to verify their usefulness. Especially with $B$-amylase we can assume seasonal variation of activity, since it is a storage protein. With another wild barley strain studied later, we have direct evidence at the DNA level using restriction endonuclease fragmentation and probing with a barley $\beta$-amylase specific probe, the large AccI fragment of the plasmid pcßC51 (KREIS et al. 1987), that a different $\beta$-amylase allele has been recombined in a backcross derivative, also showing increased enzyme activity (unpublished data).

Among the $\mathrm{F}_{1}$ 's of 248 Israeli $H$. spontaneum accessions crossed with cv. Adorra by AHOKAS (1981) there were $4.8 \%$ partially sterile $F_{1}$ 's, whose pattern fitted with translocation heterozygosity. Translocation heterozygosity is known to cause a variable degree of floret sterility, in the 35 cases in barley on average $42 \%$ (BURNHAM et al. 1954).
After a backcross, the level of $4.8 \%$ of rearrangements is not necessarily any significant problem for breeding, unless a specific gene is linked with the translocation breakpoint, or a selected translocation homozygosity is associated with an inferior behaviour as a cultivar.

In the original habitats of wild barley, B-glucanase and especially $\beta$-amylase show negative correlations between parameters describing the availability of moisture in the environment and enzyme activity (AHOKAS and NASKALI 1990 b). The reason for this must be adaptive. Domesticated barley does not necessarily show such a correlation, because its life span is different, involving i.a. storage of the grains sheltered and not in the soil.

Acknowledgements. We are obliged to Prof. Erkki Kivi for the opportunity to grow material in the field of the Hankkija Plant Breeding Institute. Ms. Anneli Kaseva helped prepare the graphs. The study was partly supported with grants from the Foundation for Biotechnical and Industrial Fermentation Research and from the Ministry of Agriculture and Forestry. H. Ahokas' study was partly done under the auspices of the Academy of Finland.

\section{References}

AнокAS, H. 1977. Lysine and tryptophan content of some high-protein stocks and species of Hordeum. Hereditas 86: 143-145.

- 1981. Cytoplasmic male sterility in barley. X. Distribution of msm 1 fertility restoration ability in the wild progenitor of barley in Israel. Ann. Bot. Fenn. 18: 313-320.

- 1982. Variation of kernel protein and lysine in the wild progenitor of barley. Hereditas 96: 29-37.

- 1990. Hordeum spontaneum as a source of variation of grain composition. Sver. Utsädesför. Tidskr. 100: 86-87.

— \& NASKALI, L. 1990 a. Variation of $\alpha$-amylase, $\beta$-amylase, $\boldsymbol{B}$-glucanase, pullulanase, proteinase and chitinase activity in germinated samples of the wild progenitor of barley. J. Inst. Brew. 96: 27-31.

— \& NASKALI, L. 1990 b. Geographic variation of $\alpha$-amylase, $\beta$-amylase, B-glucanase, pullulanase and chitinase activity in germinating Hordeum spontaneum barley from Israel and Jordan. Genetica 82: 73-78.

BOURNE, D.T. \& PIERCE, J.S. 1970. B-Glucan and B-glucanase in brewing. J. Inst. Brew. 76: 328-335.
Brown, A.H.D. \& JACOBSEN, J.V. 1982. Genetic basis and natural variation of $\alpha$-amylase isozymes in barley. Genet. Res. 40: 315-324.

Brown, A.D.H., Munday, J. \& Oram, R.N. 1988. Use of isozyme-marked segments from wild barley (Hordeum spontaneum) in barley breeding. Plant Breed. 100: 280288.

Burnham, C.R., White, F.H. \& Livers, R. 1954. Chromosomal interchanges in barley. Cytologia 19: 191-202.

ChoJeCKi, J. BARnes, S. \& Dunlop, A. 1989. A molecular marker for vernalisation requirement in barley. In: Helentjaris, T. \& Burr, B. (eds.). Development and application of molecular markers to problems in plant genetics. Cold Spring Harbour Laboratory Press, Cold Spring Harbour, NY. p. 145-148.

CORKE, H. \& ATSMON, D. 1988. Amino acid resources of the wild relative of barley (Hordeum spontaneum) in Israel. Plant Breed. 101: 89-94.

DoLL, H. \& BRown, A.H.D. 1979. Hordein variation in wild (Hordeum spontaneum) and cultivated (H. vulgare) bar- 
ley. Can. J. Genet. Cytol. 21: 391-404.

Ellis, R.P., Forster, B.P., Thomas, W.T.B. \& Nevo, E. 1991. The use of Hordeum spontaneum Koch in barley improvement. In: Munck, L. et al. (eds.). Barley Genetics VI, vol. 1. Munksgaard, Copenhagen. p.65-67.

FrIEDMAN, M. \& ATSMON, D. 1988. Comparison of grain composition and nutritional quality in wild barley (Hordeum spontaneum) and in a standard cultivar. J. Agric. Food Chem. 36: 1167-1172.

KIRSI, M. 1973. Formation of proteinase inhibitors in developing barley grain. Physiol. Plant. 29: 141-144.

- \&AнокAS, H. 1983. Trypsin inhibitor activities in the wild progenitor of barley. Phytochemistry 22: 27392740.

Kreis, M., Williamson, M., Buxton, B., Pywell, J., HejGAARD, J. \& SVEnDSEN, I. 1987. Primary structure and differential expression of $\beta$-amylase in normal and mutant barleys. Eur. J. Biochem. 169: 517-525.

-, Williamson, M.S., Shewry, P.R., Sharp, P. \& Gale, M. 1988. Identification of a second locus encoding Bamylase on chromosome 2 of barley. Genet. Res. 51: 1316.

LADIZINSKY, G. 1975. Collection of wild cereals in the Upper Jordan Valley. Econ. Bot. 29: 264-267.

LitTs, J.C., Simmons, C.R., Karper, E.E., Huang, N. \& RODRIGUEZ, R.L. 1990. The isolation and characterization of a barley 1,3-1,4-B-glucanase gene. Eur. J. Biochem. 194: 831-838.

Loi, L., Ahluwalia, B. \& Fincher, G.B. 1988. Chromosomal location of genes encoding barley (1->3, 1->4)-B-glucan 4-glucanohydrolases. Plant Physiol. 87: 300-302.

LUNDGARD, R. \& SvensSon, B. 1987. The four major forms of barley $\beta$-amylase. Purification, characterization and structural relationship. Carlsberg Res. Commun. 52: 313-326.

MacLeod, L.C., LanCe, R.C.M. \& Brown, A.H.D. 1991. Chromosomal mapping of the Glb1 locus encoding (1->3),(1->4)-B-D-glucan 4-glucanohydrolase EI in barley. J. Cereal Sci. 13: 291-298.

Nevo, E. 1992. Origin, evolution, population genetics and resources for breeding of wild barley, Hordeum spontaneum, in the Fertile Crescent. In: Shewry, P.R. (ed.). Barley: genetics, biochemistry, molecular biology and biotechnology. CAB International, Oxon. p. 19-43.

-, Beiles, A., Storch, N., Doll, H. \& Andersen, B. 1983. Microgeographic edaphic differentiation in hordein polymorphisms of wild barley. Theor. Appl. Genet. 64 : 123-132.
Pan, S.-M., Chang, T.-C., Juang, R.-H. \& Su J.-C. 1988. Starch phosphorylase inhibitor is B-amylase. Plant Physiol. 88: 1154-1156.

Pedersen, S. 1988. Pollen competition in barley. Hereditas 109: 75-81.

Preece, I.A. \& Hoggan, J. 1956. Enzymic degradation of cereal hemicelluloses. I. Observations on the B-glucosanase system and its development during malting. J. Inst. Brew. 62: 486-496.

Slakeski, N., Baulcombe, D.C., Devos, K.M., Ahluwalia, B., DOAN, D.N.P. \& FINCHER, G.B. 1990. Structure and tissue-specific regulation of genes encoding barley (1->3,1->4)-B-glucan endohydrolases. Mol. Gen. Genet. 224: $437-449$.

Smith, P.K., Krohn, R.I., Hermanson, G.T., Mallia, A.K., Gartner, F.H., Provenzano, M.D., Fujmoto, E.K., GoEKE, N.M., OLSON, B.J. \& KLENK, D.C. 1985. Measurement of protein using bicinchonic acid. Anal. Biochem. 150: 76-85.

Sopanen, T. \& LaURIERE, C. 1989. Release and activity of bound B-amylase in a germinating barley grain. Plant Physiol. 89: 244-249.

StUART, I.M., LoI, L. \& Fincher, G.B. 1986. Development of $(1->3,1->4)-B$-D-glucan endohydrolase isoenzymes in isolated scutella and aleuron layers of barley (Hordeum vulgare). Plant Physiol. 80: 310-314.

TAKAHASHI, R. \& HAYASHI, J. 1964. Linkage study of two complementary genes for brittle rachis in barley. Ber. Ôhara Inst. Landwirtsch. Biol., Okayama Univ. 12: 99105.

— \& YASUDA, S. 1971. Genetics of earliness and growth habit in barley. In: Nilan, R.A. (ed.). Barley Genetics II. Washington State Univ. Press, Pullman, WA. p. 388408.

VISURI, K. \& NUMmI, M. 1972. Purification and characterisation of chrystalline B-amylase from barley. Eur. J. Biochem. 28: 555-565.

WoODWARD, J.R. \& FinCHER, G.B. 1982. Purification and chemical properties of two 1,3;1,4-B-glucan endohydrolases from germinating barley. Eur. J. Biochem. 121: 663-669.

Manuscript received June 1992

Hannu Ahokas

Maria J. Erkkilä

Agricultural Research Centre of Finland

Institute of Plant Breeding

SF-31600 Jokioinen, Finland 


\title{
SELOSTUS
}

\section{Itämisaikaisen B-amylaasin ja B-glukanaasin aktiviteettimuuntelu linjoissa, jotka on jalostettu spontaneum-villiohrien takaisinristeytyksistä Adorra-lajikkeella}

\author{
Hannu Ahokas ja Maria J. ERKKILÄ \\ Maatalouden tutkimuskeskus ja Helsingin yliopisto
}

Villiohran (Hordeum spontaneum) takaisinristeytyksestä viljaohran Adorra-lajikkeella on valintajalostuksella kehitetty viljaohran kaltaisia linjoja, joiden perimästä laskennallisesti on $25 \%$ villiohrasta. $\mathrm{F}_{6}$-polvea edustavasta, idätetystä jyvämateriaalista on määritetty $B$-amylaasi- ja B-glukanaasiaktiivisuudet in vitro yhteensä 219:sta linjasta jyvämassaa ja liukoista proteiinia kohti laskettuna. Linjat perustuvat kahdeksaan eri villiohrakantaan, joista seitsemässä on löydetty korkea aktiivisuus jommastakummasta entsyymistä tai molemmista.

Rekombinanttilinjoja, joihin on todennäköisesti siirtynyt korkea B-amylaasiaktiivisuus, saatiin suhteellisen usein lähes kaikista korkean $\beta$-amylaasin omaavien villiohrien ris- teytyksistä. Korkea B-glukanaasiaktiivisuus periytyi linjoihin harvinaisemmin. Ohran B-glukanaasigeeni saattaa olla kytkeytynyt johonkin villin kasvin ominaisuutta määräävăän geeniin, jonka voimakkaan karsimisen kautta on usein menetetty myös villiohran B-glukanaasialleeli valintapolvien aikana. Siten B-glukanaasialleelia rekombinoitaessa villiohrasta viljaohramuotoihin on käytettävä varsin laajaa materiaalia. Kun aktiivisuudet lasketaan näytteen proteiinia kohti, villiohran korkea proteiinipitoisuus (tavallisesti yli 20 \%) saattaa näennäisesti madaltaa suurenkin entsyymiaktiivisuuden. Osassa rekombinanttilinjoja alentunut proteiinipitoisuus sinänsä tuo esiin korkean, proteiiniin suhteutetun entsyymiaktiivisuuden. 